\section{Las carencias de la democracia actual y las limitaciones de las teorías de la transición H.C.F. Mansilla}

H.C.F. Mansilla es Doctor en Filosofía por la Universidad Libre de Berlín. Fue Profesor de esa Universidad y Profesor Visitante de la Universidad de Zurich; ha sido Research fellow de la Comunidad Científica Alemana, de la Ford Foundation y de la Fundación Volkswagen-Stiftung; es miembro correspondiente de la Real Academia Española y de la Academia Norteamericana de la Lengua Española (New York), y miembro de número de la Academia de Ciencias de Bolivia. E-mail: hcf_mansilla@yahoo.com

\section{Resumen}

El ensayo esboza una crítica a las teorías de la transición democrática y seguidamente trata de mostrar las limitaciones de toda democracia de masas contemporánea. Las teorías de la transición son calificadas de institucionalistas porque descuidan el "país real», atribuyendo una importancia exagerada al "país legal». El autor propone un cuestionamiento de fenómenos que estas teorías presuponen como positivos: los enfoques contractualistas, la modernidad y la globalización, el crecimiento económico incesante, la mercantilización de toda la vida social, la expansión de los medios masivos de comunicación, la calidad ética e intelectual de las élites gobernantes y la falta de una concepción del bien común.

\section{Summary}

This essay is an attempt to criticize the theories of democratic transition and beyond it to exhibit the limitations of all contem-porary mass democracies. The transition theories are charac-terized as institutionalist because they neglect the "real coun-try" and attribute an excessive importance to the "legal country». The phenomenon which are positive for the transition theories must be put into question: contractualist perspectives, unrestricted economic growth, modernity and globalization, the mercantile conception of social life, the expansion of mass media, the ethic and intellectual quality of ruling elites and the lack of a working conception of common welfare. 